\title{
Bank's Rating a Need or Necessity in Albanian Banking System
}

\author{
Ada Aliaj Phd. Candidate \\ Lecturer at the "Aleksander Moisiu" University, Durres, Albania \\ Tel: 0692967409 e-mail: aliajada@yahoo.com
}

Ilir Hoti Phd.

Lecturer at the "Aleksander Moisiu" University, Durres, Albania Tel: 0692058426 e-mail: ilirhoti@yahoo.com

\section{Doi:10.5901/mjss.2013.v4n10p490}

\begin{abstract}
Financial Transactions have increased and have become more complex over this 20 years. This paper examines the importance of credit ratings assigned to banks in Europe and the positive and negative impacts. We will also see Albanian Banking system over the last 5 years focusing on the risks it faces. The aim of this article is to analyze and identify the importance of Banks' Rating. Actually, banks are the dominant sector within Albanian financial system, managing more than $95.5 \%$ of total financial assets. Although banks sometimes use internal models as a substitute for credit ratings for their credit assessments, the internal models themselves often tend to rely heavily on ratings for actual or methodological input. Investors' reliance on credit ratings has increased over the past 30 years. Acquiring information is costly, particularly for fixed income investors, given collective action problems. Thus investors seek to outsource creditworthiness assessments to rating agencies. Finally we will see if there is a need of Banks Rating in Albanian's Banks, the requirements of Basel III and the regulatory of the Bank of Albania.
\end{abstract}

Keywords: Credit rating, Rating agencies, Banking system.

\section{The importance of Bank's Rating}

Compared to other corporations, banks pose a particular challenge for external rating agencies. Banks are inherently opaque and exposed to a multiplicity of risks. Bank business is characterized to a significant extent by asymmetries of information and actual(and potential) regulatory interventions. We may therefore consider that bank ratings provide a lower bound (or worst-case setting) for the quality of external ratings compared to other corporate ratings ${ }^{1}$ At the same time, banks' central role in credit intermediation is important for efficient allocations of capital and risk, and thus for activity in the real economy. The collapse in credit supply during the financial crisis of 2008-09 led to a long-lasting reduction in the level of output relative to the pre-crisis trend ${ }^{2}$. Publicly funded recapitalization and guarantees on deposits and debt put pressure on the credibility of sovereigns' signatures. These considerations compound the economic Importance of unbiased and efficient assessments of bank creditworthiness. The particular role of credit ratings in the financial system is enshrined in policy. From 1936 onwards, regulatory authorities in the United States have, in many instances, delegated oversight of the credit quality of banks' portfolios to rating agencies ${ }^{3}$. For instance, in exchange for liquidity, central banks require a minimum quality of collateral, defined in many cases by reference to credit ratings. In the realm on prudential banking regulation, the Basel II accord increased regulatory reliance on credit ratings. Under this agreement, minimum capital levels are specified as a proportion of risk-weighted assets, where risk weights may be calculated using credit ratings. Yet compared with the unweighted leverage ratio, there is no evidence to suggest that the risk-weighted capital ratio is a superior predictor of bank failure during crisis periods ${ }^{4}$. Moreover, anecdotal evidence suggests that although large banks sometimes use internal models as a substitute for credit ratings for their credit assessments, the internal models themselves often tend to rely heavily on ratings for actual or methodological

\footnotetext{
1 Morgan, 2002

2 Reinhart and Rogoff, 2009; Campello et al, 2010

${ }^{3}$ White, 2010

${ }^{4}$ Mariathasan and Merrouche, 2012
} 
input. The Basel III agreement expresses a broad intention to mitigate reliance on ratings of securitized loans, but introduces an additional role for credit ratings with respect to counterparty credit risk from over-thecounter derivatives 5 .

The credit ratings of Moody's, Standard and Poor's, and Fitch play a key role in the pricing of credit risk. This role will be further expanded with implementation of the Basel-2 Ac-cord, which requires rating estimations of bank partners' credit risk.

These ratings are especially important for banks in developing countries, since eco-nomic agents there do not have long experience with the market economy and so are not highly experienced in estimating risks. There are in fact few firms in these countries that have ratings by the international rating agencies. For example, at the end of 2007, only 84 of 1135 Russian banks had Moody's ratings (about 120 had at least one rating by an inter-national rating agency).

In practice, such models could be used by banks (in implementing the Basel-2 IRB approach) and by bank supervision authorities (as part of an Early Warning System, EWS), especially in developing countries, where there are still many banks without ratings.

At present, it appears virtually certain that a reformed Accord will offer a ratings-based "risk-bucketing" system of one form or another. In such a system, banking book assets are grouped into "buckets," which are presumed to be homogeneous. Associated with each bucket is a fixed capital charge per dollar of exposure. In the latest version of the Basel proposal for an Internal Ratings-Based ("IRB") approach (Basel Committee on Bank Supervision 2001), the bucketing system is required to partition instruments by internal borrower rating; by loan type (e.g., sovereign vs. corporate vs. project finance); by one or more proxies for seniority/ collateral type, which determines loss severity in the event of default; and by maturity. More complex systems might further partition instruments by, for example, country and industry of borrower. Regardless of the sophistication of the bucketing scheme, capital charges are portfolio-invariant, i.e., the capital charge on a given instrument depends only on its own characteristics, and not the characteristics of the portfolio in which it is held. I take portfolio-invariance to be the essential property of ratings-based capital rules.

As envisaged in the Basel II framework: The term "rating system, comprises all of the methods, processes, controls, and data collection and IT systems that support the assessment of credit risk, the assignment of internal risk ratings, and the quantification of default and loss estimates.

\section{Bank`s rating in Albania}

Eevidences shows that the costs of banking crises in terms of lost economic growth are higher than in industrial countries, and problems in a single bank have a high probability of turning into a systemic crisis. Indeed, in contrast with industrial countries, it is difficult to find episodes in emerging markets where the failure of an important bank has not been accompanied by a systemic crisis. Systemic failures in the financial system are typically complex and they differ one from the other. In order to understand the processes involved it is necessary to schematize and simplify, but extreme reductionism is misleading. As the causal mechanisms are not fully understood, it is unwise to rely on a classification by supposed cause. Instead, as is done with diseases which are not well understood, we can classify by the characteristic group of symptoms displayed - the syndrome.

Many banking system crises in developing countries seem endemic, displaying a recurrent pattern of distress with insolvency and illiquidity (usually traceable to pervasive government involvement) persisting for years. Other countries have experienced epidemics, sometimes involving macroeconomic collapses, sometimes not. Each of these categories shares some symptoms with the others, but a review of the characteristics of a large number of developing country cases suggests that the syndromes are distinctive. ${ }^{6}$ The search for warning signals and prevention mechanisms needs to take this into account.

Since Albania is classified as a developing country, it's a necessity for Albanian banks assessing their performance. Till now Albanian Banks have never been experienced Bank`s Rating, and still remain a big challenge for them. Although some of the Banks have Internal methods for assessing their performance, these methods do not provide investors, depositors and Regulative Authorities with sufficient information. So it is in charge to Rating Agencies to inform all the above mentioned parties. Rating Agencies have showed that the most common indicators used by policymakers and rating agencies in assessing banks performance in developing markets can be divided in two categories: (a) the macroeconomic environment (including the political, legal, and judicial landscape) and (b) microeconomic factors as represented by bank-specific financial ratios. The main question we ask is: Should rating agencies and policymakers use similar bank financial ratios to those developed in industrial countries?

${ }^{5} \mathrm{BCBS}, 2010$

${ }^{6}$ Honohan "Banking system failures In developing and transition countries: Diagnosis and prediction" 1997. 
Indicators of bank strength can be summarized in five key variables. Together, these variables--capital adequacy, asset quality, management, earnings, and liquidity-are called the CAMEL system (or a variation of it), a system widely used by bank supervisors in industrial countries. Capital adequacy, asset quality, and liquidity are the three most important indicators.

In the case of banking supervisors, reports by the US Treasury indicate that this system has functioned relatively well. That capital adequacy the core ratio used by banking supervisors is also a key financial indicator used by credit rating agencies in emerging markets is stressed in the following statement by Moody.s: .The strength of capital and provisions is a more important element in the analysis of emerging market banks than is the case with banks in developed markets ${ }^{7}$. Traditional indicators work where two sets of conditions are met. The first set relates to the quality of data and the supervisory framework, and the second to the existence and efficiency of markets ${ }^{8}$. Data quality, supervision and the existence of efficient markets remains a challenge for the Albanian banks. Having studied all the macroeconomic factors(Political, legal, and juridicial landscape, Financial markets, Interconnections between Banking and Insurance industries, Monetary market, Government borrowing from banks, Financial derivatives) and micro factors, we stopped at the most important, namely the quality of data that is closely linked to risk Accounting, Provision for credit losses, Possessive structure of Banks in Albania, Operational Risk.

\section{Accounting risk}

Its obviosly that the account risk is high even though since 2009 banks report under IFRS. Without underestimating the positive achievements its necesseary to underline these issuses:

Banks do not use homogeneous methods for identifying and managing toxic assets. We will try to see Mechanism of Clean and Cost of toxic assets used by Albanian Banks.

In all developed countries, including the U.S. banks recovery techniques for toxic assets remains the same, buying them from governments. Basically, the outstanding loans of banks' portfolio return into government spending potency, which financially, means that their cost is distributed to taxpayers ${ }^{9}$. Impact of acquisition from banks of some of their toxic assets or loans backed by subprime mortgages or complex derivatives is essentially, a transfer of financial risk from the banking system in fiscal system. However, buying these securities faces a major challenge - no one knows how to price them.

Even in Albania, expectation is the same, the problem of the cost of such an operation, whether it faces government liquidity or borrowing from it, remain serious challenge. In the U.S., the Treasury Department has hired experts to evaluate their pricing with methods which are mainly based on the discounted cash flow that actualize the future values in current values, but again, these estimates will be substantial margin assumptions for error.

Here appears the mutual impact of the Banking Industry Financial System which generates a dichotomy between Monetary Policy and Fiscal Policy. On the other hand, we ponder to understand that exposure to information asymmetry, prioritization, risk measurement and control of the Ex-Ante and Ex-Post is basically the key to communicating vessels between banks and fiscal structures. Receive generates aggregate credit to the Government [ie VAT from purchases on credit], but on the other hand, not settlement of loans, the cost of bad debt and derivatives related to all legal disputes with market collateral contracts and insurance guarantees reduce the bank's assets, creating capital scarcity.

Motivated by the Basel III, the risk of Capital Adequacy in Banks is modeled as a function of risk and operational risk and further Operational Risk as proof of financial risk. Here we see the proposed site for Key Risk Indicators [KRI] to be calculated, reported and analyzed by a systematic periodicity and uniformity.

The presence and quality of functioning of the Early Warning System [EWS] -Convergence/Divergence of IFRS and Basel III. EWS system serves to identify problems early in time, before they become larger and turn into losses that require additional cost in time, money and human effort. The fact that the level rate of bad loans has grown up rapidly, argues and simultaneously alerts for the establishment of such a system:

As we see the percentage trend of bad loans, means that loans are not classified and reported correctly so financial statement are not true.

\footnotetext{
${ }^{7}$ Moddys 1999

8 Liliana Rojas-Suarez "Rating Banks in Emerging Markets"

${ }^{9}$ Hoti Ilir 2012
} 
Table 1.

\begin{tabular}{|l|c|c|c|c|}
\hline$\%$ of bad loans & 2009 & 2010 & 2011 & $2012^{10}$ \\
\hline$[\approx 3$ times ] Banks & $6,5 \%$ & $8,7 \%$ & $14,4 \%$ & $22,8 \%$ \\
\hline $\begin{array}{l}{\left[\approx 2 \text { times] Non banks }{ }^{11}\right.} \\
{[\text { Besa, PSHM, FAF, etj.] }}\end{array}$ & $8,3 \%$ & $10,2 \%$ & $13,4 \%$ & $16,8 \%$ \\
\hline
\end{tabular}

\section{Financial Reports Quality Portfolio}

Quality indicators of risk in the portfolio are the first priority list of reporting because of their importance in banking institutions. To avoid misinterpretations, no indication should be assessed in isolation from the others. For example, a portfolio risk assessment should always include write off credit report and credit report rescheduling.

Portfolio at Risk (portfolio loans)

For internal financial management, is suggested appropriate indicators percentage of delinquent portfolio to total portfolio. For example, portfolio at risk over 10 days for weekly loan repayment; portfolio at risk over 30 days for monthly loan repayment. If using a mixture of frequencies settlement, termination for each 30-day results as the most appropriate option.

It is recommended a 90-day outage for external reporting, because the result is generally more representative for the long-term loss.

To rescheduled loans, portfolio at risk should be assessed individually and interpreted carefully than done for a standard portfolio. Loans that have fallen out of status once before as overdue loans, credit risks are greater than the whole portfolio.

It is suggested that the evaluation report should use the bank indicator of portfolio at risk and no indication of the portfolio in arrears. This is because the portfolio in arrears concentrates more on settlements that are overdue than on the entire loan balance.

Portfolio in arrears should not be used because it provides no benefit to other indicators of portfolio and risk underestimates the problems of loan repayment.

\section{Provision for credit losses (loans Write-Off)}

All banking institutions must build up realistic and accurate reserves for loan losses, reflecting both the size of the portfolio and the costs for them. Any failure of loan in a year, cost burdens for business next year. Reserve analysis should be undertaken on a monthly basis if the system allows it. To determine the most appropriate provisions, there is a wide variety of techniques:

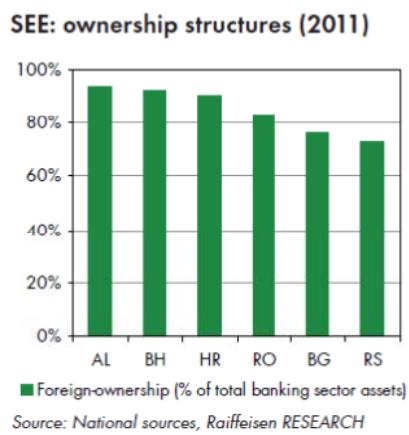

Chart 1.

Provision for loan losses increses while the age of loans increases.

${ }^{10}$ Albanian Banks Association (2012 unaudited)

11 MixMarket (www.mixmarket.org) 
C8 Report (Report on the age structure of loans and reserve calculation) summarizes information for PAR(portofolio at risk), and enables the creation of an appropriate reserve based on this information.

Reserve is calculated by multiplying balance at risk for each age category with a percentage that reflects the possibility of losing credit.

\section{Table 2}

\begin{tabular}{|l|c|c|c|}
\hline \multicolumn{2}{|l|}{ Emërtimi } & $\begin{array}{c}\text { Uncollected } \\
\text { percentage }\end{array}$ & $\begin{array}{c}\text { Calculated } \\
\text { losses }\end{array}$ \\
\hline Standard [without past due] & 51000 & $1 \%$ & 510 \\
\hline 1-30 days past due & 29000 & $1 \%$ & 290 \\
\hline 31-90 days past due & 15000 & $5 \%$ & 750 \\
\hline$>90$ days past due & 5000 & $100 \%$ & 5000 \\
\hline TOTAL (31/12) & 100000 & $8,55 \%$ & 8550 \\
\hline
\end{tabular}

If there is a surplus reserve account for 7500 , it should account for the difference revised $(1550=8550-7500)$ by an increase in reserves. Bank of Albania score determines the correction of the reserve account each month, so in the end these are almost no difference. (BOA).

Percentages for each group / segment of loans are placed above and constantly reviewed by the supervisor

If the supervisory authorities do not specify what percentage should be applied to each group for provisioning time delay for settlement, BANK department risk itself or a specialized institution outside may suggest levels of rates based on historical experience of a group of loans .

4.Undetected risk, software, procedures, systems( the importance of Internal audit)

5.Banks in Albania do not report capital as per Basel II requirements.

6. Capital structure of banks in Albania is almost entirely foreign owned. The high level of capital belonging to foreign residents creates a moral hazard and Albania has the highest level of this indicator in the region. If we compare with analog developing countries, such as Bosnia and Herzegovina, Croatia, Romania, Bulgaria and Russia, Albania banking system totally alien to their level of uncontested. On the other hand as the two banks [RBAL and BKT] are funding $65 \%$ of the budget deficit, creates a dependency of sovereign debt with non local creditors.

Some authors consider these investments, indicators of attraction of host country [Albania], but it does not mean that the attraction of investment banks turns into sustainability inevstments and on the other hand, the main reason of their investment is the positive differential in the rate of profit and gradients risk. In fact, the weight of bad loans to GDP has increased by an average pace for over $15 \%$ for the last 3 years. This indicator of long-term sustainability affects banks totally foreign.

7. Performance of bad loans increased by $5 \%$ cumulative average by 2008 , to $23 \%$ in 2012 is associated with increased number of clients with problems of the financial year. This gives the impression that banks have higher efficiency in processing files every year before 2012 because the number of files loans is declining before 2012.

\section{Table 3}

\begin{tabular}{|l|l|l|l|l|}
\hline $10 \%$ of files 2008 & $18 \%$ of files 2009 & $22 \%$ of files 2010 & $25 \%$ of files 2011 & $20 \%$ of files 2012 \\
\hline
\end{tabular}

We note that impression is because paradox that occurs while on the job experience grows, increase the number of files with problems. The second argument from the following scenario.

8. During this period Banks have experienced a high turnover of staff and especially in credit risk department. This was more evident during 2008-2011 and declined in 2012. Averaged in each bank, each credit employee has an experience with one or two other banks.

\section{Table 4}

\begin{tabular}{|l|l|l|l|l|}
\hline $33 \%$ staff turnover & $26 \%$ staff turnover & $24 \%$ staff turnover & $24 \%$ staff turnover & $18 \%$ staff turnover \\
\hline
\end{tabular}


From a survey conducted, the highest level of staff turnover has been higher initially to FEFAD to RBAL from NCB to RBAL from RBAL to Emporiki and ProCredit, etc. ${ }^{12}$. Typical for example, departures from NCB to RBAL from NCB to Intesa, the NCB to NBG. While the staff at NCB entries for 2008-2009 are mainly from universities. and NCB.

9. For each new unit staff from universities, has increased the growth of the refusal of files, especially for RBAL

\section{Table 5}

\begin{tabular}{|c|c|c|c|c|}
\hline $\begin{array}{c}13 \% \text { rejection rate } \\
\text { from firms } \\
\text { applications }\end{array}$ & $\begin{array}{c}19 \% \text { rejection rate } \\
\text { from firms } \\
\text { applications }\end{array}$ & $\begin{array}{c}23 \% \text { rejection rate } \\
\text { from firms } \\
\text { applications }\end{array}$ & $\begin{array}{c}32 \% \text { rejection rate } \\
\text { from firms } \\
\text { applications }\end{array}$ & $\begin{array}{c}36 \% \text { rejection rate } \\
\text { from firms } \\
\text { applications }\end{array}$ \\
\hline
\end{tabular}

If we compare these two banks we notice that RBAL is characterized by high turnover of senior staff, and NCB middle staff. $75-80 \%$ of the movements are focused in two departments [Credit and Risk], 15\% of the movements are for front office staff and only $1 \%$ of the movements are for human resources departments.

On the other hand the quality of refusals of applications for loans is hit, because maintaining a disbelief attitude from 13\% to $36 \%$ of files (around 3 times more) means that employees are experiencing a high degree of subjective uncertainty that is based on the type of false positive errors, then when can reject a loan application that should have been approved. This attitude comes out of average risk a bank should take, creating the type of risk avers banker that works 'to be in'. While banks have invested in training for operational risk [after 2010], for credit products and while the quality of accounting information has increased again. That is., That soon the bank will report the basic conflict-agent, or shareholding dispute between the parties seeking profit maximization and bank managers who seek to maximize their wage or their remuneration. This conflict also noted the fact that banks have reduced efforts to limit their investment in risk and are considered to invest most of the portfolio in Treasury Bills that are risk-free.

This scenario raises the question, do shareholders bank need a staff bank to invest in treasury bills, while they can do it themself?

10.Viewing 4-lending standards, individual files are rejected by almost two times lower than the rejected records from businesses. It argues that the preceding scenario, ie, that banks perceive more risk to businesses rather than individuals. According to the doctrine of the structure of risk based on term loan (term structure of risk) bankers tend to adopt to 1.6 times the short-term loans (<1 year) than long term loans of 1-5 years, but on the other hand approve the loan easier ie. long term, for the home over 10 years.

Table 6

\begin{tabular}{|c|c|c|c|c|}
\hline $\begin{array}{c}11 \% \text { refusal rate } \\
\text { for applications } \\
\text { from } \mathrm{PI}\end{array}$ & $\begin{array}{c}12 \% \text { refusal rate } \\
\text { for applications } \\
\text { from } \mathrm{PI}\end{array}$ & $\begin{array}{c}14 \% \text { refusal rate } \\
\text { for applications } \\
\text { from } \mathrm{PI}\end{array}$ & $\begin{array}{c}12 \% \text { refusal rate } \\
\text { for applications } \\
\text { from } \mathrm{PI}\end{array}$ & $\begin{array}{c}14 \% \text { refusal rate } \\
\text { for applications } \\
\text { from } \mathrm{PI}\end{array}$ \\
\hline
\end{tabular}

This forms a moral hazard because the credit employee is experiencing permanent stay in the bank, but when he finds himself within the bank, generating unit risk (risk originating unit) he adopts the term loan very easily, because he sees himself transferred from the bank, while not approve medium-term loans because he feels the responsibility of the risk of his career. And this is the fundamental problem-agent again.

Some banks like NCB, RBAL, etc. have reacted by revising labor contracts. The reason that RBAL has ceased or remove senior staff relates to the fact that is the bank that has suffered severe losses in -eg., client unit, Norga beers for 10 million Euros. The same is seen in the smaller banks eg, to Veneto Bank, NBG, where the level of judicial editing files has the highest level.

11. Referring to the chart, we see that the severity of bank lending standards begins in 2009 , when banks reflected the structure of accounting information in credit risk. In this year occurred the greatest migrations from 'standard loans' in credit 'sub-standard' and 'doubtful', but in subsequent years the migration of loans from credit flow prevails in 'suspicious' on loan 'loser' and following the write off or sell the collateral. In parallel with the banking conservatism tightening lending standards, has been a lowering of demand for loans. This creates what is known as 'blocking of credit' (Credit Crunch).

12 Hoti Ilir 2012 
This scenario issue weaknesses risk department, which does not take into account diversification through countercycle, he has done the opposite, has tightened standards for credit when demand falls. This again limits the returns to all employees' responsible departments.

\section{Conclusions}

1. MF mandatory requirement to translate the existing framework of banking accounting under International Financial Reporting Standards, imposes deep examination of the quality of banks' loan portfolio for the presence of 'damaged credit'.

2. It is necessary for Banks the use fohomogeneous methods for identifying and managing toxic assets.

3. It is well recognized that traditional bank ratios such as the capital-to-risk-weighted asset ratio are useless indicators of bank strength when accounting standards and reporting systems are inappropriate, nonperforming loans are classified inadequately, and reserves against credit losses are underprovisioned. In addition, a deficient legal framework, unable to enforce supervisory actions when a bank's performance is deemed faulty, seriously undermines the effectiveness of bank ratios ${ }^{13}$.

4. Data quality, supervision and the existence of efficient markets remains a challenge for the Albanian banks.

5. Bank ratings is a necesseaty for Albanian Banking Industry, even though the difficulties that rating agencies will face, starting by the deficiency of existing framework, Provision for credit losses, capital structure, staff and other macroeconimic factors.

\section{References}

Bank of Albania Annual Report 2012

Fitch IBCA. 2000. .Everything you wanted to know about Fitch IBCA and the BIS/Basle/ rules but were too afraid/too baffle to ask., March.

Fitch IBCA. 1998. .Bank Rating Methodology., April.

Goldstein, M., G. Kaminsky and C. Reinhart. 2000. Assessing Financial Vulnerability: An Early Warning System for Emerging Markets, Institute for International Economics, Washington, DC. 28

Honohan, Patrick and Daniela Klingebiel. 2000. Controlling Fiscal Costs of Banking Crises. World Bank, Washington, DC (May).

Honohan, Patrick. 1997. .Banking System Failures in Developing and Transition Countries: Diagnosis and Prediction., BIS Working Papers no. 39 (January). Bank for International Settlements, Basel, Switzerland.

Lane, William R., Stephen W. Looney and James W. Wansley. 1996. .An Application of the Cox Proportional Hazards Model to Bank Failure., Journal of Banking and Finance, 10: 511-31.

Liliana Rojas-Suarez "Rating Banks in Emerging Markets"

Lindgren, Carl-Johan, Tomas Balino, Charles Enoch, Anne-Marie Gulde, Marc Quintyn, and Leslie Teo. 1999. Financial Sector Crisis and Restructuring: Lessons from Asia, Occasional Paper 188. Washington, DC: International Monetary Fund.

Martin, Daniel. 1997. .Early Warning of Bank Failure.. Journal of Banking and Finance, 1: $249-76$ (November).

Moody.s Investors Service. 1999. .Rating Methodology: Bank Credit Risk in Emerging

Rojas-Suárez, Liliana, and Steven Weisbrod. 1997. Toward an Effective Financial Regulatory and Supervisory Framework for Latin America: Dealing with the Transition, in Safe and Sound Financial Systems: What Works for Latin America, Liliana RojasSuarez, ed. Inter- American Development Bank.

Sharpe, William F. 1978. Bank Capital Adequacy, Deposit Insurance and Security Values, Journal of Financial and Qualitative Analysis, Proceedings, issue 13: 701-18.

Sinkey, Joseph. 1979. Problem and failed institutions in the commercial banking industry, Contemporary Studies in Economic and Financial Analysis, vol. 4, JAl Press.

${ }^{13}$ Liliana Rojas-Suarez "Rating Banks in Emerging Markets" 